domised controlled trials, our systematic review lends support to the hypothesis that NSAIDs may protect against the development of Alzheimer's disease. The appropriate dose, duration, and ratios of risk to benefit are still unclear.

We thank Paula Rochon (Kunin-Lunenfeld Applied Research Unit and Department of Health Policy, Management and Evaluation, University of Toronto, Canada) for reviewing the manuscript.

Contributors: See bmj.com

Funding: AS is funded by a Parkinson Disease Research Education and Clinical Center (PADRECC) grant. ME and SG are funded by Canadian Institutes of Health Research (CIHR) postdoctoral fellowship awards.

Competing interests: None declared.

1 In't Veld BA, Ruitenberg A, Hofman A, Launer LJ, Van Duijin CM, Stijnen $T$, et al. Nonsteroidal antiinflammatory drugs and the risk of Alzheimer's disease. N Engl J Med 2001;345:1515-21.

2 Zandi PP, Anthony JC, Hayden KM, Mehta K, Mayer L, Brietner JC, et al. Reduced incidence of AD with NSAID but not $\mathrm{H}_{2}$ receptor antagonists: the Cache County study. Neurology 2002;59:880-6.

3 Breitner JC, Zandi PP. Do nonsteroidal antiinflammatory drugs reduce the risk of Alzheimer's disease? N Engl J Med 2001;345:1567-8

4 McGeer PL, Schulzer M, McGeer EG. Arthritis and anti-inflammatory agents as possible protective factors for Alzheimer's disease: a review of 17 epidemiologic studies. Neurology 1996;47:425-32.

5 Fourrier A, Letenneur L, Begaud B, Dartigues JF. Nonsteroidal anti-inflammatory drug use and cognitive function in the elderly: inconclusive results from a population-based cohort study. J Clin Epidemiol 1996; $49: 1201$

6 Amar K, Wilcock G. Vascular dementia. BMJ 1996;312:227-31.

7 The Canadian Study of Health and Aging: risk factors for Alzheimer's The Canadian Study of Health and Aging: risk
disease in Canada. Neurology 1994;44:2073-80.

Beard CM, Waring SC, O'Brien PC, Kurland LT, Kokman E. Nonsteroida anti-inflammatory drug use and Alzheimer's disease: a case-control stud in Rochester, Minnesota, 1980 through 1984. Mayo Clin Proc 1998:73:951-5.

9 Stewart WF, Kawas C, Corrada M, Metter EJ. Risk of Alzheimer's disease and duration of NSAID use. Neurology 1997;48:626-32.

10 Breitner JC, Gau MW, Welsh KA, Plassman BL, McDonald WM, Helms $\mathrm{MJ}$, et al. Inverse association of anti-inflammatory treatments and Alzheimer's disease. Neurology 1994;44:227-32.

11 Henderson AS, Jorm AF, Christensen H, Jacomb PA, Korten AE. Aspirin, anti-inflammatory drugs and risk of dementia. Int J Geriatr Psychiatry 1997;12:926-30

12 Breitner JC, Welsh KA, Helms MJ, Gaskell PC, Gau BA, Roses AD, et al. Delayed onset of Alzheimer's disease with nonsteroidal antiinflammatory and histamine $\mathrm{H}_{2}$ blocking drugs. Neurobiol Aging inflammatory $16: 523-30$

13 Lindsay J, Laurin D, Verreault R, Hebert R, Helliwell B, Hill GB, et al. Risk factors for Alzheimer's disease: a prospective analysis from the Canadian study of health and aging. Am J Epidemiol 2002;156:445-53.

14 Chen P, Ratcliff G, Belle SH, Cauley JA, DeKosky ST, Ganguli M. Cognitive tests that best discriminate between presymptomatic $\mathrm{AD}$ and those who remain nondemented. Neurology 2000;55:1847-53.

15 Ho L, Purohit D, Haroutunian V, Luterman JD, Willis F, Naslund J, et al. Neuronal cyclooxygenase 2 expression in the hippocampal formation as a function of the clinical progression of Alzheimer disease. Arch Neurol 2001;58:487-92

16 Cryer B, Feldman M. Cyclooxygenase-1 and cyclooxygenase-2 selectivity of widely used non steroidal anti-inflammatory drugs. Am J Med 1998:104:413-21.

17 Aisen PS, Schmeidler J, Pasinetti GM. Randomized pilot study of nimesulide treatment in Alzheimer's disease. Neurology 2002;58:1050-4.

18 Scharf S, Mander A, Ugoni A, Vajda F, Christophidis N. A double-blind, placebo-controlled trial of diclofenac/misoprostol in Alzheimer's disease. Neurology 1999;53:197-201.

19 Aisen PS. Evaluation of selective COX-2 inhibitors for the treatment of Alzheimer's disease.J Pain Symptom Manage 2002;23:S35-40.

20 Petersen RC, Doody R, Kurz A, Mohs RC, Morris JC, Rabins PV, et al. Current concepts in mild cognitive impairment. Arch Neurol Current concept

21 Egger M, Zellweger-Zähner T, Schneider M, Junker C, Lengeler C, Antes G. Language bias in randomised controlled trials published in English and German. Lancet 1997;350:326-9

(Accepted 6 May 2003)

\title{
Prevalence of five common clinical abnormalities in very elderly people: population based cross sectional study
}

\author{
A J M de Craen, J Gussekloo, Y K O Teng, P W Macfarlane, R G J Westendorp
}

As the prevalence of disease rises with age, the number of people with unidentified abnormalities is also likely to increase. We assessed the number of previously known and newly identified patients with anaemia, diabetes mellitus, thyroid dysfunction, atrial fibrillation, and hypertension in a population based sample of 85 year old people.

\section{Participants, methods, and results}

The study design and baseline characteristics of the 599 participants in the Leiden 85 plus study have been published elsewhere. ${ }^{1}$ All participants gave informed consent. We used standard laboratory techniques to identify anaemia, diabetes mellitus, and thyroid dysfunction. Atrial fibrillation, including flutter, was identified on an electrocardiogram. Hypertension was identified by averaging two standardised blood pressure readings measured with a sphygmomanometer at two separate visits. For 40 people a blood sample, electrocardiogram, or blood pressure measurement was not available. Furthermore, we excluded all 31 residents of nursing homes because they do not voluntarily consult a general practitioner but are continuously monitored by a nursing home physician.
We obtained the medical history of the 528 remaining people from their general practitioner. By including a local general practitioner (JG) in our research team, we managed to get all 60 general practitioners in Leiden to cooperate with us. Moreover, all pharmacies in Leiden provided detailed information on prescribed drugs for all patients. All drugs were encoded according to the WHO Anatomical Therapeutic Chemical (ATC) classification. ${ }^{2}$

Abnormalities were considered known when a positive medical history was present or when patients were currently using one of the following ATC coded drugs: B03 for anaemia, A10 for diabetes mellitus, H03 for thyroid dysfunction, B01AA04/B01AA07 combined with C01AA05 for atrial fibrillation, or C02, C03, C07, C08, or C09 for hypertension.

The definitions for newly identified clinical abnormalities were: haemoglobin $<130 \mathrm{~g} / \mathrm{l}(<8.1 \mathrm{mmol} / \mathrm{l})$ in men or $<120 \mathrm{~g} / \mathrm{l}(<7.5 \mathrm{mmol} / \mathrm{l})$ in women for anaemia $^{3}$; non-fasting serum glucose concentrations $>11.0 \mathrm{mmol} / \mathrm{l}$ for diabetes mellitus; serum thyroid stimulating hormone $<0.3 \mathrm{mU} / \mathrm{l}$ and serum free thyroxin $>24 \mathrm{pmol} / \mathrm{l}$ (hyperthyroidism) or thyroid stimulating hormone $>4.8 \mathrm{mU} / \mathrm{l}$ and free thyroxin $<10$ $\mathrm{pmol} / \mathrm{l}$ (hypothyroidism) for thyroid dysfunction; Min-
Section of Gerontology and Geriatrics, Department of General Internal Medicine, Leiden University Medic Centre, PO Box 9600, $2300 \mathrm{RC}$, Leiden, Netherlands

A J M de Craen senior epidemiologist J Gussekloo general practitioner Y K O Teng medical student R G J Westendorp professor

University of Glasgow, Department of Medical Cardiology, Royal Infirmary, Glasgow, G31 2ER P W Macfarlane professor

Correspondence to: A J M de Craen craen@lumc.nl

BMJ 2003;327:131-2 
Number (percentage) of people previously known and newly identified with clinical abnormalities in population of 528 people aged 85 years and their contact with general practitioner in year before study

\begin{tabular}{|c|c|c|c|c|}
\hline \multirow[b]{2}{*}{ Clinical abnormality } & \multicolumn{2}{|c|}{ Abnormality } & \multicolumn{2}{|c|}{ No GP contact } \\
\hline & Known & Newly identified & Known & Newly identified \\
\hline Anaemia & $38(24)$ & $118^{\star}(76)$ & $0 / 38(0)$ & $8 / 118(7)$ \\
\hline Diabetes mellitus & $77(90)$ & $9(10)$ & $4 / 77(5)$ & $0 / 9(0)$ \\
\hline Thyroid dysfunction & $32(84)$ & $6(16)$ & $3 / 32(9)$ & $0 / 6(0)$ \\
\hline Atrial fibrillation & $32(58)$ & $23(42)$ & $0 / 32(0)$ & $5 / 23(22)$ \\
\hline Hypertension & $304(81)$ & $73(19)$ & $15 / 304(5)$ & $7 / 73(10)$ \\
\hline
\end{tabular}

${ }^{*}$ Mean corpuscular volume $<80 \mathrm{fl}$ in six participants and $>100 \mathrm{fl}$ in six participants.

nesota codes $8-3-1$ or $8-3-2^{4}$ for atrial fibrillation or flutter; and systolic pressure $>160 \mathrm{~mm} \mathrm{Hg}$ or diastolic pressure $>95 \mathrm{~mm} \mathrm{Hg}$ for hypertension.

Among the 528 participants 38 were known to have anaemia, 77 had diabetes mellitus, 32 had thyroid dysfunction, 32 had atrial fibrillation, and 304 had hypertension (table). We newly identified 118 with anaemia, 9 with diabetes mellitus, 6 with thyroid dysfunction, 23 with atrial fibrillation, and 73 with hypertension (table). Over 90\% of all participants, except for those with newly identified atrial fibrillation, had consulted their general practitioner at least once in the year before the study.

\section{Comment}

Using information from general practitioners and pharmacy records combined with five simple and readily available procedures we have obtained reliable estimates of the prevalence of five common clinical abnormalities in very elderly people. We found a considerable number with previously undetected anaemia and hypertension but fewer with previously undetected thyroid dysfunction, atrial fibrillation, and diabetes mellitus. We have shown that our criteria for anaemia, diabetes mellitus, thyroid dysfunction, and hypertension are adequate for elderly people and can serve as guidelines for clinicians treating older patients. Experienced staff reviewed all automated interpretations and codings of electrocardiograms for atrial fibrillation so we consider that our interpretation of this abnormality is completely reliable. In conclusion, we have shown that it is feasible to use these investigative procedures in an elderly population to provide important quantitative information for future discussions on screening elderly people.

Contributors: AJMdC,JG, and RGJW designed the study. AJMdC and YKOT performed the statistical analysis. PWM analysed ECG recordings. All authors interpreted the results and contributed to writing the paper. AJMdC is guarantor for the study.

Funding: None

Competing interests: None declared.

Ethical approval: The Medical Ethical Committee of the Leiden University Medical Centre approved the study.

1 Von Faber M, Bootsma-van der Wiel A, van Exel E, Gussekloo J, Lagaay $\mathrm{AM}$, van Dongen E, et al. Successful aging in the oldest old. Who can be characterized as successfully aged? Arch Intern Med 2001;161:2694-700.

2 World Health Organization. Guidelines for ATC classification and DDD assignment. Oslo: WHO Collaborating Centre for Drugs Statistics Methodology, 1996.

Izaks GJ, Westendorp RGJ, Knook DL. The definition of anaemia in olde persons. JAMA 1999;18:714-7.

Macfarlane PW, Latif S. Automated serial ECG comparison based on the Minnesota code. J Electrocardiol 1996;29(suppl):29-34.

5 Topol EJ, Califf RM, Isner, J, Prystowsky EN, Serruys PW, Swain JL, et al. Textbook of cardiovascular medicine. Philadelphia: Lippincott-Raven, 1998. (Accepted 10 June 2003)

\section{Longevity and carrying the C282Y mutation for haemochromatosis on the HFE gene: case control study of 492 French centenarians}

Hélène Coppin, M Bensaid, S Fruchon, N Borot, H Blanché, M P Roth

Unité de

Physiopathologie Cellulaire et

Moléculaire, CNRS

UPR 2163, CHU

Purpan, 31059

Toulouse Cedex 3,

France

Hélène Coppin

research scientist

M Bensaid

PhD student

S Fruchon

PhD student

$\mathrm{N}$ Borot

research scientist

MP Roth

research scientist

continued over

BMJ 2003;327:132-3
Hereditary haemochromatosis is a common autosomal recessive disorder of iron metabolism. Most patients are homozygous for a C282Y mutation in the HFE gene. This mutation is frequent in northern Europe, where one in five to ten people are carriers. People who are heterozygous for the C282Y mutation have slightly but significantly higher values for serum iron and transferrin saturation and are less likely to have anaemia because of iron deficiency. ${ }^{12}$

Iron promotes the generation of free radicals, which leads to mutagenesis, atherosclerosis, inflammation, and bacterial growth. Therefore, genotypes that increase the concentrations of iron for transport and storage may be associated with an increased risk for common diseases, such as cancers and cardiovascular diseases, and for inflammatory and infectious conditions. Other studies, which investigated the associations of C282Y heterozygosity with morbidity, found conflicting results, and consensus has not been reached about whether C282Y is associated with the development of extrahepatic cancers, coronary heart disease, or diabetes. ${ }^{12}$

We hypothesised that people who are heterozygous for the C282Y mutation are under-represented in a centenarian population because many would have died younger from life threatening diseases which are more prevalent in C282Y heterozygotes.

\section{Participants, methods, and results}

We recruited 492 French centenarians, who consented personally, through the Chronos Project at the Foundation Jean Dausset (Centre d'Etude du Polymor- 